\title{
An Empirical Study of Brand Loyalty on Samsung Electronics in Pakistan
}

\author{
Faiq Kamal Haider Hashmi \\ Department of Management Sciences, The Islamia University of Bahawalpur (Pakistan)
}

Faisal Khalid

Department of Management Sciences, The Islamia University of Bahawalpur (Pakistan)

Muhammad Ammar Akram

Department of Management Sciences, The Islamia University of Bahawalpur (Pakistan)

\section{Usman Saeed}

Department of Management Sciences, The Islamia University of Bahawalpur (Pakistan)

\author{
Muhammad Rizwan (Corresponding author) \\ Lecturer, Department of Management Sciences, \\ The Islamia University of Bahawalpur, Pakistan \\ E-mail: rizwan.arshad@iub.edu.pk
}

Doi:10.5296/ jsr.v5i1.6570 URL: http://dx.doi.org/10.5296/ jsr.v5i1.6570

\begin{abstract}
The purpose of this study is to explore the brand loyalty of Samsung electronics focusing the special part of south Punjab of Pakistan (Bahawalpur and Multan). This projected model is examines major variables moderating the relationships of, brand trust, service quality, brand credibility, customer satisfaction, brand image with these challenging models of the relationships amongst the impact of, independent variables on brand loyalty. The data was collected from the students of Department of management sciences. Questionnaire was dispersed and self administrated to 150 respondents. The study implies some analysis scales to check the data, which include regression analysis, reliability analysis and different scales
\end{abstract}


of measuring frequencies of the respondents. The present study shows that brand credibility, customer satisfaction and service quality has a positive effect on brand loyalty. Brand trust and brand image has positive effect on service quality.

Keywords: Brand loyalty, brand image, brand trust, customer satisfaction, perceived quality.

\section{Introduction}

There are many definitions that express or define what a brand is but an easy and simple definition is: Brand is the name of symbol, logo, term, or anything that differentiates a product from another is called brand. Coming towards brand loyalty we came to know that the reusing of a brand shows the repurchasing behavior of a consumer. A brand loyal consumer always shows faith on the company or brand and in return the company provides better services and also shows their faith on consumers. So these both are inter-linked with each other. When expectations of the consumers are fulfilled then consumer will remain loyal to the brand, similarly another factor that travel parallel with expectation is willingness, if there is willingness to repurchase a brand than the consumer will buy it otherwise expectation doesn't means that the consumer will buy this brand. Brand loyal customers are willing to pay more for a brand they like.

Sometimes people associate themselves with a brand and it became a part of their life, some people are egoistic, they use a brand repeatedly to look different and show their status, similarly some people associates themselves with the brand that it become their identity, they want themselves to recognized through a brand. There are many examples like most of the famous personalities became the brand ambassador of a brand and always recommend those brands to others.

There are many types of brand loyalty which are discussed all over the world namely are:

Hard-core loyal: those consumers who buy the same brand all the time.

Split Loyal: Those consumers who are loyal to only two or more brands at the same time.

Shifting Loyal: These are the consumers who do not stick to a same brand rather they switch from brand to brand.

Switchers: These are the consumers who are not loyal they are just switchers.

Brand loyalty is the consumers perception and behavioral response towards a brand. Another factor that influences and effects brand loyalty is self-congruity (likeliness) for a brand, if the consumer like a brand than definitely he will buy that brand every time due to his likeliness. Product involvement and brand loyalty are two important concepts that contain a significant proportion of consumer choices, many studies show this relationship as for instance, (Taylor, 1981, 1983; Leclerc and Little, 1977) and many other references. Peer pressure is also an important factor that influences consumers in buying a brand i-e: family, friends, and social media, etc. these things change the mind of the consumer and sometimes change the thoughts towards the brand. 
So as brand influence the attitude of the purchaser in relation to the re-purchase process and affects his or her attachment to the brand that stems from the persuasion of its strength and influence. Moreover, brand develops an association with the customer, whether a positive association by being loyal to the brand or negative association by switching the brand.

Peer pressure also influences consumers in buying brand i-e: family, friends and social media, etc. These things change the mind of the consumer and sometimes change the thoughts towards a brand. Brand loyalty is preferred all over the world by different companies/organizations because they consider it a way of selling their products as they think that attaining more customers will give boost to their sales and making them loyal makes their goodwill even better. Companies prefer to create word of mouth through the customers because customers are the best source to advertise a product and make more loyal customers.

The variables that are to be discussed further in this paper are as follows: customer loyalty(it refers to the loyalty of the customers that how much loyal the customers are with the brand), brand credibility(it is the likeliness of the brand, customers affiliation with the brand and customer preferences about the brand),brand personality(people associates themselves a brand with their personality and makes it a way of expressing their selves and try to show their status according to the brand), brand image(this is the image of brand customers mind that how a customer feels about a brand and what is the image of that brand in his/her mind), store image(it is the outlook of the store that company is managing to attract the customers towards the brand and store by making it more attractive and beautiful), peer pressure(these are the contextual factors or influential groups that influence the customers in making choices and changing their decisions), services quality(these are the services that company offers to their customers after selling their product which maybe warranty/guarantee or any other useful service), perceived quality(customer perception about the brand and their thinking about the product), and advertising(the way through which brand information reached to the customers). Sometimes companies focus on single variable to understand the customers more deeply and attain more and more customers. These variables have a great impact on brand loyalty, to make customers loyal companies do a lot of efforts and a lot of research to understand customers mind and likeliness, so that they can design such a product that meet the criteria of customers wants and needs. It has also seen that contextual factors play an important role for creating brand loyalty because they create a brand image in customers mind and motivate the customers to think about the brand. As one thought also motivates the customers to at least try the brand one time.

These are the variables on which brand loyalty depends because brand loyalty itself is not an independent variable as it depends on many factors some of which we will discuss in detail further. Satisfaction level is needed in brand loyalty because if the customer is satisfied with the brand and always willing to purchase the same brand then this thing also motivates the customer to buy the same brand again and again. 


\section{Literature review}

\section{Brand loyalty:}

It is been said by the Aaker in 1992 that brand loyalty implies regularly two factors that is purchase of a specific brand and satisfactory attitude towards a brand. Brand loyalty progresses when expectations from the brands fits, personality or self-image of the consumer or when the brand offers satisfactory and exclusive benefits that is pursues by the customers. A customer could be loyal to the brand if ones limited their dealings and purchases to this brand even though others brands offering better products..

The significance of brand loyalty has been renowned in the marketing literature for at least three decades (Howard and Sheth 1969). In this decades Aaker (1991) has conversed the role of loyalty in the brand equity process and has specifically renowned that brand loyalty leads to positive marketing advantages like reduced, marketing costs, more new customers, and greater trade leverage. In addition Dick and Basu (1994) advocate other loyalty-related marketing advantages, such as word of mouth and greater resistance among loyal consumers to competitive strategies. In another opinion, we could also say that customers may be loyal because they are pleased or satisfied with the brand, and consequently want to continue the relationship (Fornell, 1992).

\section{Customer Satisfaction:}

Customer satisfaction is very much important in order to make it brand loyal, that's why many companies as well as organizations try to satisfy their customers first prior to any other needs. In marketing we say that customer is the king and most of the companies agreed to this point because customers are the most important asset of the company. That why while designing any product the company keeps in mind customers demands and its needs.

There are several practical studies that indications satisfaction is an originator of brand attitude, brand post purchase intention, and attitudinal brand loyalty for consumer retailing services (Oliver, 1980; Pritchard et al., 1999; Russell- Bennett et al., 2007; Rizwan et al., 2013). Satisfaction is established for the growth of loyalty when brand loyalty is dignified in a number of successive purchases of the identical brand (LaBarbera and Mazursky, 1983). Similarly, research has exposed that evaluation of a retail service following purchase and consumption leads to two aspects of brand loyalty-- purchase loyalty and attitudinal loyalty-which play a serious role in defining whether the consumer will purchase that service again (Bennett, Härtel, and McColl- Kennedy, 2005; Chaudhuri and Holbrook, 2001). However, research on satisfaction and brand loyalty from the perspective of Chinese retailing services is not well documented. Similarly performance leads to customer satisfaction (Olive, 1997 ; Olsen, 2002). Thus, the following hypothesis is arrived:

H1: Customer Satisfaction has positive and significant impact on brand loyalty.

\section{Service Quality:}

Supplying higher quality services and giving customer with continuous and excellent services lead into competitive advantages for service organizations. Most important competitive 
advantages include competitive obstacles, supplying exceptional products, mitigating marketing costs and customers' loyalty (Rusta, 2008: 4 -9). Service quality is a focused evaluation that exhibits the customer's perception of elements of service such as interaction quality, physical environment quality, and outcome quality. These elements are in turn examined based on specific service quality ranges; reliability, assurance, responsiveness, empathy and tangibles. Parasuraman (1988) defined service quality as worldwide judgment or attitude relative to the overall brilliance or superiority of the service. According to studies by Lefkowit and Clark (1998) and Morrall (1993) to differentiate services as similar as goods, one should not only distinguish them in terms of name or logo but also in terms of a set of customers' conceptions that are defined well.

Small empirical research has focused explicitly on the association between service quality, brand trust and loyalty. With regards to behavioral motive in a service settings, Zeithaml et at.(1996) considered a comprehensive, multi-dimensional framework of customer behavioral motivations in services. This framework was initially compromised of the following four main ranges: word-of-mouth communications, buying intention, price sensitivity and complaining behavior. The above discussions suggest the following hypotheses:

H2: Service quality has positive and significant impact on brand loyalty.

\section{Brand Trust:}

We define brand trust as the willingness of the average customer to depend on the ability of the brand to perform its stated function (Moormal et al 1993). Moorman, Zaltman, and Deshpande (1992) and Doney and Cannon (1997) both also emphasis that the notion of trust is only related in situations of ambiguity (e.g., when greater versus fewer differences among brands occur). exclusively, trust decreases the ambiguity in an environment in which customers experience particularly vulnerable because they know they can rely on the trusted brand. Doney and Cannon

(1997) propose that the makeup of trust includes a "calculative process" rely on the capability of an object or party (e.g., a brand) to carry on to meet its responsibility and on an estimation of the costs against rewards of staying in the relationship. At the same time, Doney and Cannon found that trust have an inference regarding the benevolence of the firm to do something in the greatest welfare of the consumer based on common goals and values.

Brand trust leads to brand loyalty or obligation because trust develops switch over relationships that are extremely valued (Morgan and Hunt 1994, Chaudhuri and Holbrook, 2001). In different words, trust and commitment should be linked, because trust is significant in relational exchanges and commitment is also set aside for such appreciated relationships. In this association, Moorman, Zaltman, and Deshpande (1992) and Morgan and Hunt (1994) discover that trust leads to commitment in business-to-business relational interactions. Trusted brands should be purchased more frequently and should suggest a superior degree of attitudinal commitment. The above discussions suggest the following hypotheses: 


\section{Macrothink}

H3: Brand trust has positive and significant impact on service quality.

\section{Brand Image:}

Keller(1993) elaborates brand image as multi-type of brand linkage as well as the Favorability, potency and individuality of these associations. Thaker (2006) explains that brand image can be a thought of natural characters and it has a special relation to brand identity concept. Aaker defines the brand identity as a set of human characteristics weaved in a brand. Personality stimulation assessments give details why a customer may keep emotional dependency to a brand but not to another one (Brodie et al, 2009).

Brand Image is the set of beliefs held about an exacting brand" (Kotler, 1988).

Brand Image is a set of associations, usually prepared in some significant way" (Aaker, 1992). Gardner and Levy have been recognized (Levy 1958) with crystallizing "brand image" in a significant form in their classic 1955 article. Criticizing previous research for being too superficial in its focus on stereotypical purchase reasons, they discovered that it was time to scratch under the surface and recognize more enduring motivations for purchase. Their conception was that goods had a social and psychological nature as well as a bodily one, and that the sets of feelings, ideas and attitudes that customers had about brands, their "image" of brands, were vital to buying choice.

In drawn model, brand image specifically the relatives are presented that cause brand and logo awareness and differentiate them from services.

H4: Brand image has positive and significant impact on service quality.

\section{Brand credibility}

Brand credibility is a multi-characteristic expression that imitates the integrity of the brand in the eyes of the customer. The characteristics of the term involve the consistency of the brand in terms of claim explanation, honesty, trust-spreading and delivering what is shown by the producer. Stating plainly, brand credibility is a three-fold expression necessitating reliability, expertise and pleasant appearance (Sternthal and Craig, 1982; Erdem and Swait, 2004). Brand credibility is measured as an significant factor impacting the brand's customer base and its market share (Chaudhuri and Holbrook, 2001).Brand signaling theory alsopeeps into this meaning by implying the application of brand credibility in fabricating brand equity (Erdem and Swait, 1998). Brand producers are steadily in search of motivators that can yield, appreciably, towards the augmentation of brand credibility. Having the trust that the brand warrants its publicized character can build up a strengthened and ongoing reliance between the producer and its consumer.

H5: Brand Credibility has positive and significant impact on brand loyalty. 


\section{1l Macrothink}

Figure.1

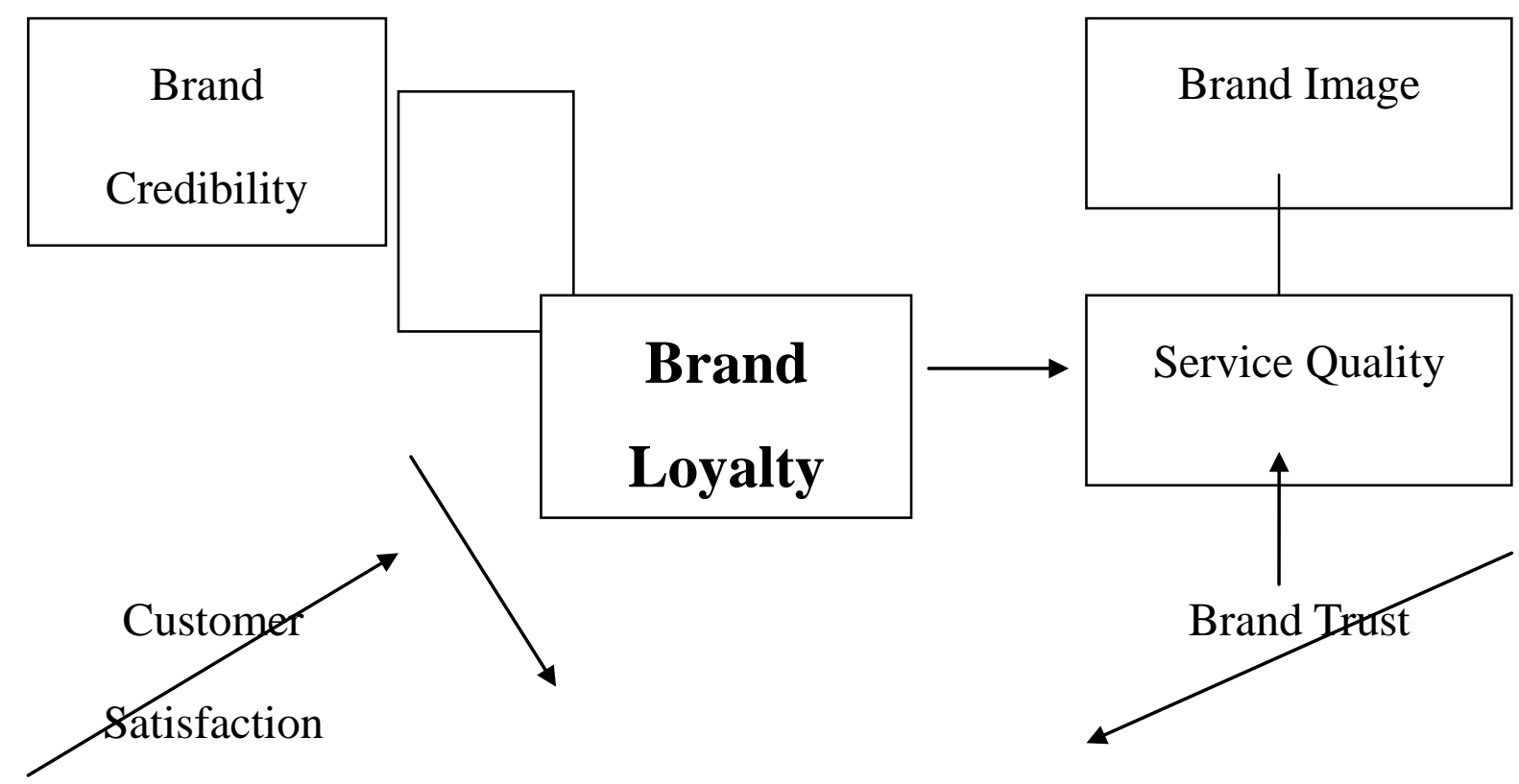

\section{Research Methodology:-}

The current research is expressive. Expressive research can be elaborated as explaining something in more comprehensive way, and towards a more specific situation. Expressive researches are those researches which explain the existing scenario of interpreting and developing judgments (Ceswell, 1994). The major purpose of the expressive research is authentication of the produced hypothesis that supports the present condition. This form of research gives information about the present conditions and focus on previous or present for example quality of life in a community or customer attitude towards any marketing activity (Kumar, 2005).

\section{Sample/Data:-}

In order to understand the data for understanding the situation about brand loyalty, a sample of 150 respondents asked to participate in a self-administered questionnaire. The current research is brand loyal customers in Pakistan.

The present study uses a non-probability sampling system that is convenience sampling. Convenience sampling is a sampling technique that obtains and collects the relevant information from the sample or the unit of study that are conveniently available (Zikmund, 1997). Convenience sampling is normally is used for collecting a large number of completed surveys speedily and with economy (Lym et al, 2010).

It has confirmed that the sample members have enough education and awareness to appear in the self-administered survey. Initially, the participants should be loyal to the brand and having enough information about brand. 


\section{Al Macrothink}

We choose, sample members from single city of Pakistan. Two main clusters will aim to gather the sample data like university students and working professionals. The selection of students and working professionals are based on the past results of the studies on brand loyalty.

\section{Instrument and Measures:-}

The survey instrument of the current study address two major purposes: First is to analyze the relationship of different variables in the adoption of brand loyalty. Second, to collect information about the different characteristics of the respondents that can be used to understand the variations in different categories. The survey instrument contains two sections. Section 1 includes the latent variables that are important in the current study. These variables includes customer satisfaction, service quality, brand trust, brand image and brand credibility towards brand loyalty. This section of the study is developed based on the past literature and already used questionnaires (Table 1).

Section 2 includes different personal and demographic variables. This section will obtain the respondent's information about gender, age, income, education, status, shown in (Table 3 ).

\section{Procedure}

The questionnaire was distributed among 200 respondents from which only 150 are selected .The questionnaire was filled from a target population from Bahawalpur and Multan. Rest of the questionnaires was not filled properly or contained errors. Before distributing questionnaires among the respondents the purpose was clearly explained to them and the current situation was told to them. After the process of data collection the data was out into the software named SPSS for further analysis and to verify whether our data is correct or not.

\section{Reliability Analysis}

Overall Cronbach's alpha of that is more than acceptable and recommended value 0.50 by Nunnally (1970) and 0.60 by Moss et al. (1998). This shows that all the 36 items were valid and reliable and completely satisfy the measure given to check the values of cronbach's alpha. It is shown in table below.

Table.2 Reliability Of The Measured Instruments

\begin{tabular}{|l|l|l|}
\hline Scales & Items & Cronbach Alpha \\
\hline Brand Image & 5 & 0.834 \\
Brand Credibility & 7 & 0.863 \\
Brand Trust & 5 & 0.843 \\
Customer Satisfaction & 2 & 0.775 \\
Service Quality & 4 & 0.830 \\
\hline
\end{tabular}




\section{Results and Analysis}

Demographic and personal information which includes gender, age, income, education level and status of the respondents to distribute them and to know their frequency that how much respondents do we have and what is their information, the information is given in the below.

Table.3 Profile of The Respondents

\begin{tabular}{|c|c|c|c|}
\hline & Category & Frequency & Percentage \\
\hline \multicolumn{4}{|l|}{ Variable } \\
\hline \multirow[t]{2}{*}{ Gender } & Male & 79 & 52.7 \\
\hline & Female & 71 & 47.3 \\
\hline \multirow[t]{4}{*}{ Age } & $15-20$ years & 59 & 39.3 \\
\hline & 20-25 years & 87 & 58 \\
\hline & $35-40$ years & 2 & 1.3 \\
\hline & Above 40 & 2 & 1.3 \\
\hline \multirow[t]{4}{*}{ Income } & Below 15000 & 114 & 76 \\
\hline & $15000-35000$ & 23 & 15.3 \\
\hline & $35000-40000$ & 4 & 2.7 \\
\hline & Above 40000 & 9 & 6.0 \\
\hline \multirow[t]{5}{*}{ Education } & Matriculation & 10 & 6.7 \\
\hline & Inter & 8 & 5.3 \\
\hline & Bachelors & 83 & 55.3 \\
\hline & Master & 32 & 21.3 \\
\hline & MS & 17 & 11.3 \\
\hline \multirow[t]{3}{*}{ Status } & Student & 131 & 87.3 \\
\hline & Employed & 12 & 8 \\
\hline & Bachelor & 4 & 2.7 \\
\hline
\end{tabular}




\begin{tabular}{|l|l|l|l|}
\hline & Unemployed & 2 & 1.3 \\
Housewife & 1 & .7 \\
\hline
\end{tabular}

\section{Hypothesis Testing:-}

\section{Customer Satisfaction And Brand Loyalty:}

From the current study, it is being concluded that customer satisfaction has a significant and positive impact on brand loyalty. Particularly, customer satisfaction has a significant relationship with $(\beta=0.127)$ and $(p=0.001)$. It means that customer satisfaction gives $12.7 \%$ to brand loyalty. So the relationship among them is supported.

\section{Brand Credibility And Brand Loyalty:}

According to the current study it has been notices that brand credibility impacts positively and significantly on brand loyalty. Specifically brand credibility has positive impact containing $(\beta=0.460)$ and $(\mathrm{p}=0.000)$. It shows that brand credibility contribute more than $46 \%$ to brand loyalty. So the relationship is supported.

\section{Service Quality And Brand loyalty:}

Recent study proves that service quality has a significant and positive impact upon brand loyalty. It has been prove due to the results of $(\beta=0.154)$ and $(\mathrm{p}=0.05)$, which shows that service quality add up $15.4 \%$ to brand loyalty. So the relationship is supported.

\section{Brand Image And Service Quality:}

From the above study another impact also be proved that brand image has a positive and significant impact on service quality. Brand image shows current study containing $(\beta=0.187)$ and $(p=0.029)$. It shows that brand image contribute $18.7 \%$, which is supported and also proves this relationship. 


\section{Brand Trust And Brand Loyalty:}

Current study shows that brand trust has a positive and significant impact on brand loyalty. Brand trust shows that brand trust include $(\beta=0.350)$ and $(p=0.000)$ to brand loyalty, which means that this relationship is supported. It includes $35 \%$ to service quality

\begin{tabular}{|l|l|l|l|l|l|l|}
\hline Hypothesis & Model Variables & Estimate & S.E & C.R & P & Results \\
\hline H1 & $\begin{array}{l}\text { C.S } \\
\text { B.L }\end{array}$ & 0.127 & 0.039 & 3.251 & 0.001 & Supported \\
\hline $\mathbf{H 2}$ & $\begin{array}{l}\text { B.C } \\
\text { B.L }\end{array}$ & 0.460 & 0.066 & 8.236 & 0.000 & Supported \\
\hline H3 & $\begin{array}{l}\text { S.Q } \\
\text { B.L }\end{array}$ & 0.154 & 0.081 & 2.473 & 0.015 & Supported \\
\hline H4 & $\begin{array}{l}\text { B.I } \\
\text { S.Q }\end{array}$ & 0.187 & 0.085 & 2.203 & 0.029 & Supported \\
\hline H5 & $\begin{array}{l}\text { B.T } \\
\text { S.Q }\end{array}$ & 0.350 & 0.081 & 4.335 & 0.000 & Supported \\
\hline
\end{tabular}


Figure.2



\section{Discussion:}

The main objective of this study is to know and understand the brand loyalty in Pakistan. To identify that whether brand loyalty is considered among the people or not, a research was conducted, in which different variables were considered, that may affect brand loyalty possibly through a questionnaire. The results obtained from this research were analyzed, that allow us to verify the relationship among our different variables. We will discuss those variables individually to give more comprehensive and understandable idea to general public about our research.

Previous studies confirm the impact of brand credibility on brand loyalty so do this study. Brand credibility is acknowledged as a significant feature impacting the brands customers base and its market share (Chaudhuri and Hoolbrook, 2001). Brand credibility is a three-fold caption necessitating trustworthiness, expertise and attractiveness (Strnthal and Craig, 1982; Erdem and Swait, 2004). These three components made a customer loyal as the customer may find any to or maybe all three to satisfy its needs. As we say that reliability lies in the eye of the customer, it has always been seen and preferred by the customer that the brand, customer is choosing is reliable and able to meet its needs. Therefore, it has been seen that brand credibility has a positive impact on brand loyalty.

Analyzing from past researches, it has also been noticed that customer satisfaction shows a positive impact on brand loyalty. Satisfaction is found to increase loyalty when brand loyalty is measured in a number of successive purchases of the same brand (LaBarbera and Mazursky, 1983). This leads to one thing that if the customer is satisfied with the brand then its intentions to purchase the brand again would be greater. Similarly performance leads to customer satisfaction (Olive, 1997 ; Olsen, 2002). It is also been known from past researches 
that purchase intention and attitude towards a brand is originated from customer satisfaction which ultimately leads to brand loyalty.

Service quality was defined by Zeithmal (1988) as "the judgment of customers about the overall superiority of a product or service." Services are intangible in nature that's why most of the customers us the product first and then reach towards any conclusion. There are many different things that most of the customers consider are reliability, responsiveness, assurance and empathy etc. These different factors satisfy the customers and leads toward brand loyalty.

Brand Image is a set of associations, usually organized in some meaningful way" (Aaker, 1992). Brand image is customer's perception about the brand, the picture of the brand that reflects in customer's eye. With first interaction of the brand, customer usually try to anticipate the brand whether it meets their expectations or not. Brand Image is the set of beliefs held about a particular brand" (Kotler, 1988). After the brand satisfies customers needs they began to expect more from the brand and consider the brand related to their personalities. Another authors says that brand image is the association and favorite-ability of brand loyalty (Keller 1993).

Brand trust takes to brand loyalty or dedication because trust develops exchange relationships that are extremely valued (Morgan and Hunt 1994, Chaudhuri and Holbrook, 2001). There is no doubt that if the customer trust the brand than it definitely leads to brand loyalty. And this could only be achieved if the customer's needs and wants are satisfied understanding their basic and requirements. Studies found that trust is very significant to the growth of brand loyalty (Berry, 1995; Reicheld \& Schefter, 2000; Dyson, Farr \& Hollis, 1996; Morgan and Hunt 1994, Chaudhuri and Holbrook, 2001 ). As we know that brand trust leads towards brand commitment which ultimately results in brand loyalty.

\section{Limitations and Future Research:}

The current study analysis shows that the past researches conducted on brand loyalty are valid and give satisfactory results. Similarly in this research paper, many past researches are proved and reliable. There were some limitations in research which are, the sample size was very small, because of which it was difficult to make an extensive exploratory research on brand loyalty. Another limitation was, the research was conducted in particularly two cities only. The area for distributing sample was small. Few other limitations include, the data was collected from students only and there was only one brand selected (Samsung). Due to the shortage of time, the research was not given full time but hard work was assigned to it.

Future research must be improved and should be conducted on a large scale so that better results could be collected. Similarly target population should be enhanced not only students but professionals must be included. If the sample size increased than the data collected will be more reliable and better results can be obtained. 


\section{Macrothink}

\section{References:}

Chaudhuri Arjun,Holbrook B.Moris, (2001), "The Chain Of Effects From Brand Trust And Brand Affects To Brand Performance: The Role of Brand Loyalty", Journal of Marketing Vol.65, p.81-93

Erdem T, Swait J) 2004(. Brand credibility, brand consideration and choice. J Consum Res ;31:191-8

LaBarbera PA, Mazursky D (1983). A longitudinal assessment of consumer satisfaction/dissatisfaction: The dynamic aspect of the cognitive process. J. Mar. Res., 20(4): 393-404.

Oliver RL (1997). Satisfaction: A behavioral perspective on the consumer. McGraw-Hill. New York.

Olsen SO (2002). Comparative evaluation and the relationship between quality, satisfaction, and repurchase loyalty. J. Acad. Mar. Sci., 30(3): 240-249.

Zeithaml, V.A. (1988). Consumer perceptions of price, quality, and value: a means-end model and synthesis of evidence. Journal of Marketing, 52, 2-22, July.

Keller, K.L., (1993). Conceptualizing, measuring and managing customer-based brand equity. Journal of Marketing, 57, 1-22.

Morgan M.Robert \& Hunt D. Shelby, (1994), "The Commitment-Trust Theory of Relationships Marketing”, Journal of Marketing, Vol.58 (July 1994), 20-38

Chaudhuri, A., \& Holbrook, M.B. (2001). The chain of effects from brand trust and brand affect to brand performance: The role of brand loyalty Journal of Marketing, 65(2), 81-93

Berry, L. L. (1995) "Relationship marketing of services growing interest, emerging perspectives", Journal of the Academy of Marketing Science, Vol.23, No.4, pp.236-245.

Reicheld, F. F. \& Schefter, P. (2000) "E-loyalty: Your secret weapon on the web", Harvard Business Review, Vol.78, No.4, pp.105-113.

Dyson, P., Farr, A. and Hollis, N.S. (1996), "Understanding measuring, and using brand equity", Journal of Advertising Research, Vol. 36 No. 6, pp. 9-22.

Iqbal, U., Rizwan, M., Zafar, A., Khan, M. H., Usman, M. \& Iqbal, D. (2013) Determinants Uncovering the Brand Loyalty: A Signaling effect of Price on Quality Perception. Journal of Basic and Applied Scientific Research, 3(11), 212-221

Rizwan, M., Usman, A., Hussain, T., Shafiq, A., Rauf, S. \& Ayaz, Q., (2013) The Impact of the Perceived Quality, Customer Satisfaction, Brand Trust and Contextual Factors on Brand Loyalty, International Journal of Research in Commerce and Management, 4(3), 83-89

Kumar, N., Luthra, A., Datta, G., (2006), "Linkages between Brand Personality and Brand Loyalty: A Qualitative Study in an Emerging Market in the Indian Context", South Asian Journal of Management, Vol.13, No. 2, pp. 11-36. 


\section{Macrothink}

Thakor M(2006). Brand origin: conceptualization and review. J Consum Mark;13(3):27-42.

Moorman, C., Zaltman, G. \& Deshpande, R. (1992) "Relationships between providers and users of marketing research, the dynamics of trust within and between organizations", Journal of Marketing Research, Vol.29, No.3, pp.314-329.

Doney P, Cannon J(1997). An examination of the nature of trust in buyer-seller relationships. J Mark;61:35-51.

Parasuraman, A., Zeithaml, V. A., \& Berry, L. L. (1988). SERVQUAL: A multipleitem scale for measuring consumer perceptions of service quality. Journal of Retailing, 64(1), 12-40.

Bennett R, Härtel C, McColl-Kennedy JR (2005). Experience of a moderator of involvement and satisfaction on brand loyalty in a business-to-business setting 02-314R. Indus. Mar. Manage., 34: 97-107.

Oliver, R. L. (1980). A cognitive model of the antecedents and consequences of satisfaction decisions. Journal of Marketing Research, 17(4), 460-469.

. (1993). Cognitive, affective and attribute bases of the satisfaction response. Journal of Consumer Research, 20(3), 418-430.

- (1997). Satisfaction: A behavioral perspective on the consumer. New York: Irwin/McGraw-Hill.

Pritchard MP, Havitz ME, Howard DR (1999). Analyzing commitment loyalty link in service contexts. J. Acad. Mar. Sci., 27(3): 333-348.

Fornell, C. (1992). A national customer satisfaction barometer: The Swedish experience. Journal of Marketing, 56(1), 1-18.

Dick, A.S., Basu, K., (1994), "Customer Loyalty: Toward an Integrated Conceptual Framework”, Journal of the Academy of Marketing Science, Vol. 22, No. 2, pp. 99-113. 